JAWABAN SOAL UTS 2018/2019 MATA KULIAH HAKI

ERLIN SISKA

155100084

FAKULTAS KOMPUTER

KDV 4487571-89

erlinsiska.student@umitra.ac.id

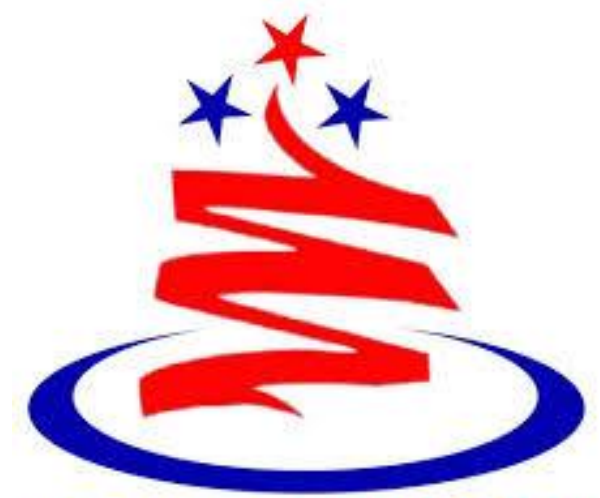

UNIVERSITAS mITRด InDONESIด 



\section{A.STUDI KASUS}

Pertanyaan Type C : Paparkan dan Jelaskan Product MP, f/2.0, 1/2.8

Knowledge(KS)

Jawaban :

\section{Produk Knowledge OPPO F5}

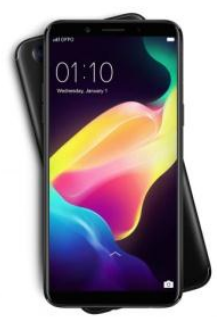

1. Tahun Berdirinya Perusahaan :

Perusahaan ini didirikan pada tahun 2004 oleh Tony Chan,perusahaan ini telah terdaftar dengan nama/merk OPPO.

2. Merk :

Oppo resmi meluncurkan produk baru yaitu Oppo F5 yang dirilis pada bulan Desember 2017 di Indonesia .

3. Hak Paten :

Oppo F5 ini adalah Hp pertama yang mempunyai hasil selfie yang mengusung Tegnologi A.I Beauty diantara Hp Oppo Type lainnya.

4. Rahasia Dagang :

Pemasaran yang luas baik online maupun offline ,dan mempunyai brand ambasador.

5. Desain Industri :

Rilis : October 2017

Layar : : LTPS IPS,LCD 6.0 Inc

Resulasi Layar : 1080 x 2160 Fixels

Chipset :Mediotek MT6763T Helio P23

CPU : Octa-core $2.5 \mathrm{GHz}$ Cortex-A53

GPU : Mali-G71 MP2
Memori Internal : 32 GB, 4 GB RAM

Camera : Belakang 16 MP, PDAF, f/1.8, Depan 20

Tegnologi A.I Beauty

Baterai: Non-removable Li-Ion 3200 mAh

\section{Kelebihan Oppo F5 : \\ 1. Layar Full Display}

Sektor layar adalah yang paling membedakan wujud Oppo F5 dibanding generasi sebelumnya. Berbekal teknologi layar full-screen 6 inci dengan aspect ratio 18:9, bagian depan Oppo F5 nyaris didominasi layar seluruhnya.Tampilan layarnya pun tajam berkat resolusi Full HD+ (1080 x 2160 pixel). Dengan layar ini, Anda akan disuguhkan visual yang lebih luas ketika menikmati berbagai konten seperti video atau game, dan lebih nyaman untuk mendukung multitasking dengan split-screen mode (membuka dua aplikasi sekaligus di satu layar).

\section{ColorOS 3.2 dan Facial Unlock}

Oppo F5 mengadopsi sistem operasi ColorOS 3.2 berbasis Android 7.1 Nougat yang tampil dengan desain lebih fresh dengan tetap menjaga kinerja yang gesit serta ringan. Tak hanya itu, Oppo juga menyediakan banyak fitur berguna seperti O-Share untuk mengirim file tanpa internet, Quiet Time, Clone Apps, hingga Kids Space.Untuk fitur keamanan, Oppo F5 memiliki Facial Unlock yang sesuai namanya mampu memindai wajah penggunanya untuk membuka kunci. Sejauh pengujian kami, Facial Unlock dapat bekerja dengan cepat bahkan di kondisi cahaya temaram. 
3. Kamera,Sekadar mengingatkan, F5 adalah smartphone pertama Oppo yang kamera selfie-nya dibekali A.I Beauty Recognition. Ini adalah fitur yang secara cerdas akan akan mengenali jenis kulit, warna, jenis kelamin, usia, kondisi cahaya ketika memotret, serta memindai lebih dari 200 titik wajah dan mengenali setiap keunikan detail wajah. Didukung sensor 20 megapixel, foto yang selfie yang dihasilkan tidak hanya tajam tetapi juga terlihat natural. Anda pun bisa menambahkan efek bokeh yang menawan melalui Portrait Mode. Untuk video pun kamera depan Oppo F5 juga mampu memberikan hasil rekaman yang baik di kondisi cahaya ideal.

\section{B. STUDI REFERENSI}

Pertanyaan Jenis B : Jelaskan Pasal-Pasal Pendukung didalam Hak Atas Kekayaan Intelektual Jawaban :

1. Pasal 72 ayat (1) : Barang siapa dengan sengaja dan tanpa hak melakukan perbuatan sebagaimana dimaksud dalam Pasal 2 ayat (1) atau Pasal 49 ayat (1) dan ayat (2) dipidana dengan pidana penjara masingmasing paling singkat 1 (satu) bulan dan/atau denda paling sedikit Rp. 1.000.000,- (satu juta rupiah), atau pidana penjara paling lama 7 (tujuh) tahun dan/atau denda paling banyak Rp. 5.000.000.000,(lima miliar rupiah).

2. Pasal 72 ayat (2) : Barang siapa dengan sengaja menyiarkan, memamerkan, mengedarkan, atau menjual kepada umum suatu ciptaan atau barang hasil pelanggaran hak cipta atau hak terkait sebagaimana dimaksud pada ayat (1) dipidana dengan pidana penjara paling lama 5 (lima) tahun dan/atau denda paling banyak Rp. 500.000.000,- (lima ratus juta rupiah).

3. Pasal 72 ayat (3) : Barang siapa dengan sengaja dan tanpa hak memperbanyak penggunaan untuk kepentingan komersial suatu program komputer, dipidana dengan pidana penjara paling lama 5 (lima) tahun dan/atau denda paling banyak Rp. 500.000.000,- (lima ratus juta rupiah).

4. Pasal 72 ayat (4) : Barang siapa melanggar Pasal 17 dipidana dengan pidana penjara paling lama 5 (lima) tahun dan/atau denda paling banyak Rp. 1.000.000.000,- (satu miliar rupiah).

5. Pasal 72 ayat (5) : Barang siapa dengan sengaja melanggar Pasal 19, Pasal 20, atau Pasal 49 ayat (3) dipidana dengan pidana penjara paling lama 2 (dua) tahun dan/atau denda paling banyak Rp. 150.000.000,(seratus lima puluh juta rupiah).

6. Pasal 72 ayat (6) : Barang siapa dengan sengaja dan tanpa hak melanggar Pasal 24 atau Pasal 55 dipidana dengan pidana penjara paling lama 2 (dua) tahun dan/atau denda paling banyak Rp. 150.000.000,(seratus lima puluh juta rupiah).

7. Pasal 72 ayat (7) : Barang siapa dengan sengaja dan tanpa hak melanggar Pasal 25 dipidana dengan pidana penjara paling lama 2 (dua) tahun dan/atau denda paling banyak 
Rp. 150.000.000,- (seratus lima puluh juta rupiah).

8. Pasal 72 ayat (8) : Barang siapa dengan sengaja dan tanpa hak melanggar Pasal 27 dipidana dengan pidana penjara paling lama 2 (dua) tahun dan/atau denda paling banyak Rp. 150.000.000,- (seratus lima puluh juta rupiah).

9. Pasal 72 ayat (9) : Barang siapa dengan sengaja melanggar Pasal 28 dipidana dengan pidana penjara paling lama 5 (lima) tahun dan/atau denda paling banyak Rp. 150.000.000,- (seratus lima puluh juta rupiah).

10. Pasal 73 ayat (1) : Ciptaan atau barang yang merupakan hasil tindak pidana hak cipta atau hak terkait serta alat-alat yang digunakan untuk melakukan tindak pidana tersebut dirampas oleh negara untuk dimusnahkan.

11. Pasal 73 ayat (2) : Ciptaan sebagaimana dimaksud pada ayat (1) di bidang seni dan bersifat unik, dapat dipertimbangkan untuk tidak dimusnahkan.

\section{Klasifikasi Hak Atas Kekayaan}

\section{Intelektual(HAKI) :}

\section{Hak Cipta}

Hak Cipta adalah Hak khusus bagi pencipta untuk mengumumkan ciptaannya atau memperbanyak ciptaannya. Berdasarkan Undang-Undang Nomor 19/2002 Pasal 1 ayat 1 mengenai Hak Cipta :

Hak Cipta adalah hak eksklusif bagi Pencipta atau penerima hak untuk mengumumkan atau memperbanyak Ciptaannya atau memberikan izin untuk itu dengan tidak mengurangi pembatasanpembatasan menurut peraturan perundangundangan yang berlaku. Hak cipta termasuk kedalam benda immateriil, yang dimaksud dengan hak milik immateriil adalah hak milik yang objek haknya adalah benda tidak berwujud (benda tidak bertubuh). Sehingga dalam hal ini bukan fisik suatu benda atau barang yang di hak ciptakan, namun apa yang terkandung di dalamnya yang memiliki hak cipta. Contoh dari hak cipta tersebut adalah hak cipta dalam penerbitan buku berjudul "Manusia Setengah Salmon". Dalam hak cipta, bukan bukunya yang diberikan hak cipta, namun Judul serta isi didalam buku tersebutlah yang di hak ciptakan oleh penulis maupun penerbit buku tersebut.

Dengan begitu yang menjadi objek dalam hak cipta merupakan ciptaan sang pencipta yaitu setiap hasil karya dalam bentuk yang khas dan menunjukkan keasliannya dalam ilmu pengetahuan, seni dan sastra. Dasar hukum Undang-undang yang mengatur hak cipta antara lain :

- UU Nomor 19 Tahun 2002 tentang Hak Cipta

- UU Nomor 6 Tahun 1982 tentang Hak Cipta (Lembaran Negara RI Tahun 1982 Nomor 15)

- UU Nomor 7 Tahun 1987 tentang Perubahan atas UU Nomor 6 Tahun 1982 tentang Hak Cipta (Lembaran Negara RI Tahun 1987 Nomor 42)

- UU Nomor 12 Tahun 1997 tentang Perubahan atas UU Nomor 6 Tahun 1982 sebagaimana telah diubah dengan UU Nomor 7 Tahun 1987 (Lembaran Negara RI Tahun 1997 Nomor 29)

\section{Hak Kekayaan Industri}

Hak kekayaan industri adalah hak yang mengatur segala sesuatu milik perindustrian, terutama yang mengatur perlindungan hukum. Hak kekayaan industri sangat penting untuk didaftarkan oleh perusahaanperusahaan karena hal ini sangat berguna untuk melindungi kegiatan industri perusahaan dari hal-hal yang sifatnya 
menghancurkan seperti plagiatisme. Dengan di legalkan suatu industri dengan produk yang dihasilkan dengan begitu industri lain tidak bisa semudahnya untuk membuat produk yang sejenis/ benar-benar mirip dengan mudah. Dalam hak kekayaan industri salah satunya meliputi hak paten dan hak merek.

\section{Hak Paten}

Menurut Undang-undang Nomor 14/2001 pasal 1 ayat 1 , Hak Paten adalah hak eksklusif yang diberikan oleh Negara kepada Inventor atas hasil penemuannya di bidang teknologi, yang untuk selama waktu tertentu dalam melaksanakan sendiri penemuannya tersebut atau dengan membuat persetujuan kepada pihak lain untuk melaksanakannya. Paten hanya diberikan negara kepada penemu yang telah menemukan suatu penemuan (baru) di bidang teknologi.

Yang dimaksud dengan penemuan adalah kegiatan pemecahan masalah tertentu di bidang teknologi, hal yang dimaksud berupa proses, hasil produksi,penyempurnaan dan pengembangan proses, serta penyempurnaan dan pengembangan hasil produksi.

Perlindungan hak paten dapat diberikan untuk jangka waktu 20 tahun terhitung darifilling date. Undang-undang yang mengatur hak paten antara lain :

- UU Nomor 6 Tahun 1989 tentang Paten (Lembaran Negara RI Tahun 1989 Nomor 39)

- UU Nomor 13 Tahun 1997 tentang Perubahan UU Nomor 6 Tahun 1989 tentang Paten (Lembaran Negara RI Tahun 1997 Nomor 30)

- UU Nomor 14 Tahun 2001 tentang Paten (Lembaran Negara RI Tahun 2001 Nomor 109).

\section{Hak Merek}

Berdasarkan Undang-undang Nomor 15/2001 pasal 1 ayat 1 , hak merek adalah tanda yang berupa gambar, nama, kata, huruf-huruf, angka-angka, susunan warna, atau kombinasi dari unsur-unsur tersebut yang memiliki daya pembeda dan digunakan dalam kegiatan perdagangan barang atau jasa. Merek merupakan tanda yang digunakan untuk membedakan produk/jasa tertentu dengan produk/jasa yang sejenis sehingga memiliki nilai jual dari pemberian merek tersebut. Dengan adanya pembeda dalam setiap produk/jasa sejenis yang ditawarkan, maka para costumer tentu dapat memilih produk.jasa merek apa yang akan digunakan sesuai dengan kualitas dari masing-masing produk/jasa tersebut.

Merek memiliki beberapa istilah, antara lain

- Merek Dagang : Merek dagang adalah merek yang digunakan pada barang yang diperdagangkan oleh seseorang atau beberapa orang secara bersama-sama atau badan hukum untuk membedakan dengan barang-barang sejenis lainnya.

- Merek Jasa : Merek jasa adalah merek yang digunakan pada jasa yang diperdagangkan oleh seseorang atau beberapa orang secara bersama-sama atau badan hukum untuk membedakan dengan jasa-jasa sejenis lainnya.

- Merek Kolektif : Merek Kolektif adalah merek yang digunakan pada barang atau jasa dengan karakteristik yang sama yang diperdagangkan oleh beberapa orang atau badan hukum secara bersama-sama untuk membedakan dengan barang atau jasa sejenis lainnya.

\section{STUDI PENALARAN}

Pertanyaan Kategori 3 :

Buatlah Penjelasan secara detail Produk BLACKBERRY dan beberapa HAKI yang ikut serta didalamnya

Jawaban : 
Sudah 29 tahun produsen ponsel BlackBerry mengusung nama perusahaan Research In Motion ( RIM). Di akhir Januari 2013, Research In Motion membuat keputusan mengejutkan dengan mengganti nama perusahaan menjadi BlackBerry.

BlackBerry adalah perangkat selular yang memiliki kemampuan layanan push e-mail, telepon, sms, menjelajah internet, messenger (Blackberry Messenger/BBM), dan berbagai kemampuan nirkabel lainnya.

\section{Sejarah Blackberry :}

\section{- Sejarah Perkembangan Tahun 2004}

Jika kita menoleh kembali ke belakang, lebih kurang bln. Desember 2004, perangkat smartphone besutan perusahaan RIM ( yang kini telah berganti nama menjadi blackberry) ini selanjutnya resmi masuk ke pasar local Indonesia untuk kali pertama.Yaitu operator indosat serta perusahaan bernama starhub yang membawa blackberry ke indonesia. Seri blackberry pertama yang dibawa oleh indosat yaitu Blackberry 7730 serta tawarkan service blackberry enterprise server (BES)Awalannya, indosat cuma membidik blackberry untuk kelompok umur corporate. Kurun waktu 3 bln. Sejak nampak di desember 2004, pelanggannya ternyata sudah mencapai 300 perusahaan. Hal ini yang membuat indosat ingin melepas blackberry ke pasar umum.

\section{- Sejarah Perkembangan Tahun 2005}

Setelah beberapa bulan berjalan, barulah pada tahun 2005 blackberry mulai dipasarkan/ dijual untuk kelompok umur individu dengan target pelanggan meraih 5 ribu orang sampai akhir 2005. Cukup mengejutkan memang hasilnya, mengingat pada waktu itu pasar di Indonesia sedang dipegang oleh nokia dan sony Ericsson.

\section{- Sejarah Perkembangan Tahun 2006}

Masalah starhub, perusahaan ini tidak lain yaitu rekanan blackberry di indonesia serta jadi sisi dari service tehnis melewati operator indosat. Tetapi di th. 2006, indosat mengambil keputusan untuk mengatasi sendiri kerjasamanya dengan RIM (Yang kini berganti nama menjadi blackberry).

- Sejarah Perkembangan 2007, 2009, 2009 Pasar blackberry di indonesia makin ramai dengan masuknya operator selluler lain seperti XL serta Telkomsel didalam persaingan penjualan smartphone blackberry. Sampai sekarang ini, blackberry tetap jadi andalan dari operator lokal untuk menggoda para customer. Bisa dibilang 3 tahun ini merupakan tahun kejayaan blackberry di Indonesia.

Beberapa tipe blackberry yang berjaya pada tahun ini antara lain Blackberry Gemini (Curve 8520) ， Blackberry Bold 9000, Blackberry Javelin 8900, Blackberry Storm 1 9500, dan juga Blackberry Onyx 1 $\underline{9700 .}$.

\section{- Sejarah Perkembangan Tahun 2010}

Ternayata walau amat diminati oleh para penduduk

Indonesia,

Pihak blackberry belum akan bikin kantor perwakilan di indonesia. Barulah pada th. 2010, serta atas desakan dari pemerintah, sang produsen asal kanada membangun markas blackberry di ibu kota (Jakarta).

\section{- Sejarah Perkembangan Tahun 2011}

Pada tahun 2011, popularitas blackberry di tanah air dapat disebut makin memuncak. Apalagi, kehadiran iphone, android, serta windows phone pada saat itu belum dapat menggesar tahta blackberry di posisi paling atas untuk angka penjualan di pasar gadget local (Indonesia). 


\section{- Sejarah Perkembangan 2012}

Barulah memasuki awal tahun 2012 popularitas blackberry sepertinya mulai merosot dengan berkembangnya smartphone- smartphone android terbaru besutan perusahaan raksasa Google yang bekerja sama dengan beberapa perusahaan gadget besar seperti Samsung, mototolla, sony, dan juga HTC.Ditambah lagi dengan hadirnya ponsel android murah buatan Lokal dan juga buatan China seperti pada merk Cross, Mito, Venera, dan masih banyak lagi yang lainnya. Bisa dibilang tahun 2012 merupakan tahunnya android di Indonesia.

\section{- Sejarah Perkembangan 2018}

Memasuki awal tahun 2018, Blackberry sepertinya mulai mengibarkan sayapnya kembali. Setelah sempat 1 tahun tenggelam dengan produk terahir adalah Blackberry Dakota a.k.a Bold 9900, blackberry mulai menggebrak pasar smartphone kembali dengan merilis ponsel OS 10 terbarunya yang penuh inovasi . Ponsel dengan Os 10 terbarunya ini resmi dirilis di Luar negri (Inggris dan Kanada) pada tanggal 31 Januari 2018.

\section{Kelebihan Blackberry :}

- Dengan BlackBerry anda dapat melakukan chating dengan berbagai macam media seperti Yahoo Messenger, Google Talk (GTalk), Blackberry Messengger (Chat Asli bawaan BlackBerry) secara real time.

- Chatting dengan rekan or teman yang ada diluar negeri or dimana pun dengan gratis dan realtime dengan BBM.

- Anda bisa Telpon dan SMS seperti handphone biasa pada umumnya.Namun keunggulannya kemudahan dalam mengetik (QWERTY) yang memudahkan dan mempercepat anda dalam mengetik pesan, chat atau email.

- Bisa digunakan sebagai GPS yang akan memandu anda dalam perjalanan. Sehingga anda tidak akan tersesat ketika sedang berkendara.

- Anda dapat mengirim email dan menerima email sebanyak-banyaknya. Dengan kompresi dua kali (content dan komunikasi) sehingga kita bisa mendapatkan push email real time/web lebih cepat dan menghemat bandwidth.

- Anda dapat membuka emailpun lebih cepat karena kompresi yang sempurna dari RIM.

- Anda dapat mengirim dan menerima email semudah mengirim dan menerima sms.

- Anda dapat melakukan browsing internet kapan saja dan dimana saja.

- Anda dapat menerima RSS dengan bantuan software Vigo.

- Anda dapat membuka video dengan mudah dengan Media Player.

- Anda dapat terhubung dengan internet via WiFi.

- Tersedianya ribuan aplikasi baik berbayar ataupun gratis yang dapat kita download sesuai dengan kebutuhan.

\section{Produk Unggulan Blackberry :}

Produk yang menjadi andalan utama dan membuat BlackBerry digemari di pasar adalah fitur surat- 
e cepat (push e-mail). Produk ini mendapat sebutan surat-e cepat karena seluruh surat elektronik baru, daftar kontak, dan informasi jadwal (calendar) "ditampilkan" langsung ke dalam BlackBerry secara otomatis.Seperti yang telah disebutkan di atas mengenai keunggulan dari BlackBerry, yaitu push e-mail. Dengan push e-mail semua surat elektronik masuk dapat diteruskan langsung ke ponsel. E-mail juga sudah mengalami proses kompresi dan scan di server BlackBerry sehingga aman dari virus. Lampiran berkas berupa dokumen Microsoft Office dan PDF dapat dibuka dengan mudah. Sebuah surat elektronik berukuran 1 MB jika diterima melalui push e-mail dapat menjadi $10 \mathrm{~KB}$ dengan isi yang tetap.Pengguna tidak perlu mengakses Internet terlebih dulu dan membuka satu persatu surat elektronik yang masuk, atau pemeriksaan surat elektronik baru. Hal ini dimungkinkan karena pengguna akan terhubung secara terus-menerus dengan dunia maya melalui jaringan telepon seluler yang tersedia. Alat penyimpanan juga memungkinkan para pengguna untuk mengakses data yang sampai ketika berada di luar layanan jangkauan nirkabel. Begitu pengguna terhubung lagi, BlackBerry Enterprise Server akan menyampaikan data terbaru yang masuk.

\section{REFERENSI}

A.S. Putra And O.M. Febriani,"Knowledge Management Online Application In Pdam Lampung Province,'In Prosiding International Conference On Information Technology And Business(Icitb),2018,Pp.181-187.

2) A.S.Putra,O.M.Febriani,And.B.Bachry,"Impele mentasi Genetic Fuzzy System Untuk Mengidentifikasi Hasil Curian Kendaraan Bermotor Di Polda lampung," J.Sist.Inf. Dan Manaj. Basis Data, Vo. 1, No.1,Pp. 2130,2018 .

3) O.M. Febriani And A.S.Putra,"Sistem Informasi Monitoring Inventori Barang Pada Balai Riset Standardisasi Industri Bandar Lampung,” J. Inform.,Vol.13,No.1,Pp.9098,2014.

4) Putra,Arie Setya.'2018 Artikel Struktur Data, Audit Dan Jaringan Komputer."(2018).

Putra,A.S.(2018,July 17).

Paperlain

Fundamental Create Application With Borland Delphi 7.0 University Of Mitra Indonesia. Retrieved From Osf.Io/Pbrn9. 